\title{
ZWIĘZŁA GENEALOGIA I ANATOMIA HABITUSU ${ }^{1}$
}

\author{
LOÏC WACQUANT
}

\section{PRZEŁOŻYŁ TOMASZ WARCZOK}

\begin{abstract}
Abstrakt: Prześledzenie filozoficznych źródeł i wczesnych zastosowań habitusu u Bourdieu które wyjaśniały historyczne zerwania, spowodowane czy to wojną wyzwoleńczą w Algierii, czy to powojenna modernizacja francuskiej wsi - pozwala na skorygowanie czterech uporczywie powracających nieporozumień dotyczących tego pojęcia: (1) habitus nie jest nigdy repliką pojedynczej struktury społecznej, stanowi raczej, wielopoziomowy i dynamiczny zestaw schematów, który podlega „permanentnej rewizji” w praktyce; (2) habitus niekoniecznie jest koherentny i spójny, odznacza się raczej zróżnicowanymi poziomami integracji i napięcia; (3) ponieważ nie zawsze pozostaje w zgodności ze światem społecznym, w którym się rozwija, habitus jest tak samo odpowiedni do analizowania kryzysu i zmiany, jak do badań spójności i trwania; (4) nie jest samowystarczalnym mechanizmem generującym działanie: wnikliwa analiza dyspozycji musi więc przebiegać w ścisłym związku z odwzorowaniem całego systemu pozycji, które naprzemiennie pobudzają, tłumią bądź przekierowują skłonności podmiotu działającego. Co kluczowe, w ujęciu Bourdieu habitus nie jest abstrakcyjną koncepcją będącą wynikiem teoretycznych dywagacji i przeznaczoną dla tego typu rozważań; jest on przede wszystkim stenograficznym sposobem wyznaczającym postawę badawcza, który stawia w sercu analizy społecznej genetyczny sposób myślenia.
\end{abstract}

Słowa kluczowe: habitus, Bourdieu, ucieleśnienie, schematy, zerwanie, historyzacja, filozofia świadomości

\footnotetext{
${ }^{1}$ Prezentowany tekst jest tłumaczeniem artykułu Loïca Wacquanta „A Concise Genealogy and Anatomy of Habitus”, który ukazał się w The Sociological Review, Vol. 64 (2016): 64-72.
} 
Uważa się czasem, że pomysłodawcą koncepcji habitusu jest Pierre Bourdieu². W rzeczywistości jest to stary filozofemat, wywodzący się z myśli Arystotelesa i średniowiecznych scholastyków, który francuski socjolog odnalazł i gruntowanie przeformułował na początku lat siedemdziesiątych dwudziestego wieku. Jego celem było wypracowanie dyspozycjonalnej teorii działania, uwzględniajacej - w ramach antropologii strukturalnej - kategorię czasu i twórcze zdolności podmiotów działających, bez popadania jednak w kartezjański intelektualizm, który silnie zniekształcił subiektywistyczne teorie działania społecznego - od behawioryzmu i fenomenologii po interakcjonizm symboliczny i teorię racjonalnego wyboru. Pojęcie habitusu odgrywa kluczową rolę w wieloletnim wysiłku Bourdieu zmierzającym do rozwinięcia nauki o praktyce i zbieżnej z nią krytyce dominacji w jej różnorodnych przejawach. Nauka ta oparta jest na potrójnej bistoryzacji: podmiotu działającego (habitus), świata (przestrzeń społeczna i pola) oraz kategorii i metod stosowanych przez analityka społecznego (refleksyjność).

Źródła habitusu odnaleźć można w pojęciu używanym przez Arystotelesa - hexis, rozwiniętym w jego doktrynie cnoty zawartej w Etyce Nikomachejskiej (350 r. p.n.e.), oznaczającym nabyty, lecz głęboko zakorzeniony stan charakteru moralnego, który ukierunkowuje nasze uczucia i pragnienia, w konsekwencji zaś samo działanie (Arystoteles 1998). W trzynastym wieku n.e. św. Tomasz z Akwinu w swej Sumie Teologicænnej (1269) przetłumaczył ten termin na łacinę jako habitus (trzeci imiesłów czasownika habere, oznaczającego posiadanie lub utrzymywanie), dodając do oryginalnego znaczenia zdolność do wzrostu poprzez sama aktywność lub też trwała dyspozycję zawieszona między potencją a celowym działaniem (Bourke 1942). Później termin używany był dość oszczędnie i raczej opisowo przez klasycznych socjologów zaznajomionych z filozofią scholastyków; wymienić tu można Émile’a Durkheima (który mówił o habitusie chrześcijańskim w swojej pracy L'évolution pédagogique en France, 1904-5), jego siostrzeńca i bliskiego współpracownika Marcela Maussa (słynne użycie terminu w eseju „Sposoby posługiwania się ciałem”, 1934), jak również Maxa Webera (w dyskusji o religijnym ascetyzmie zawartej w Wirtschaft und Gesellschaft, 1918) czy Thorsteina Veblena (który rozważał „drapieżny habitus mentalny” przemysłowców w Teorii klasy próżniaczej, 1899) ${ }^{3}$. Habitus odrodził się w fenomenologii, zwłaszcza w pracach Edmunda Husserla, który definiował go jako mentalny łącznik między przeszłym doświadczeniem a zbliżającym się działaniem. Husserl używał również pojęciowo pokrewnego terminu Habitualität, przetłumaczonego później na język angielski przez jego ucznia Alfreda Schütza jako „wiedza nawykowa” ( habitual knowledge) i w takim znaczeniu przyjętego w etnometodologii. Pojęcie to współbrzmi równocześnie z terminem habitude, rozwiniętym przez Maurice’a

\footnotetext{
2 Tak twierdzą na przykład Hans Joas i Wolfgang Knöbl w ich skądinąd miarodajnej książce Social Theory: Twenty Introductory Lectures (2009).

3 Zobacz: Durkheim (1990), Mauss (2001), Weber (2002) i Veblen (2008).
} 
Merleau-Ponty'ego, odnoszącym się do jego rozważań nad „ciałem przeżywanym”, definiowanym jako nieme, aczkolwiek inteligentne źródło znaczenia społecznego i zachowania4. Habitus pojawiał się także sporadycznie w pismach innego ucznia Husserla, Norberta Eliasa, który w klasycznym studium Über den Process der Civilisation (2014, [1939]) rozmyślał nad „psychicznym habitusem ludzi »cywilizowanych«”

Jednak dopiero w pracy Pierre’a Bourdieu, który, jako zapamiętały czytelnik Leibniza i Husserla przesiąknięty był tymi filozoficznymi dyskusjami, odnaleźć można prawdziwie socjologiczne przepracowanie pojęcia, zaprojektowanego przezeń tak, aby przekroczyć opozycje między obiektywizmem a subiektywizmem. W ujęciu Bourdieu habitus jest konstruktem mediujacym, który pomaga unieważnić zdroworozsądkową dualność tego, co indywidualne i tego, co społeczne poprzez uchwycenie ,internalizacji zewnętrzności i eksternalizacji wewnętrzności”. Chodzi więc o to, że socjosymboliczne struktury społeczeństwa zostają zdeponowane wewnątrz jednostek w formie trwałych dysposycji lub wyuczonych zdolności i skłonności do myślenia, odczuwania oraz działania w określony sposób, a te zaś z kolei kierują nimi, twórczo odpowiadając na ograniczenia i ingerencje ze strony środowiska zewnętrznego ${ }^{5}$.

Bourdieu po raz pierwszy wprowadził pojęcie habitusu na potrzeby swoich wczesnych studiów poświęconych relacjom między honorem, pokrewieństwem i władzą w społeczeństwie chłopskim swego rodzinnego Béarn (południowo-zachodnia Francja) oraz w osadach berberyjskojęzycznej części Kabylii w kolonialnej Algierii. Przy czym stereotypowa akademicka opowieść przedstawiająca Bourdieu jako apostoła „teorii reprodukcji” ukrywa fakt, że zastosował on to pojęcie, aby uchwycić dysonans (discordance) pomiędzy kulturowo określonymi zdolnościami i skłonnościami ludzi a wymaganiami wyłaniającego się systemu społecznego. Ów dysonans prowadził do historycznego zerwania i wstrząsu społecznego. W przypadku Béarn większa zdolność miejscowych dziewcząt do przyjęcia promowanych w szkole i mediach miejskich wartości skazała miejscowych mężczyzn na starokawalerstwo, doprowadzając całe społeczeństwo wiejskie, oparte na zasadzie męskiego dziedziczenia, do powolnej śmierci. W przypadku Algierii wykorzenieni fellachowie dźwigali ciężar sprzecznej mieszanki tradycyjnych i narzuconych przez kolonizację kategorii, których efekt, w postaci „kulturowego sabiru” (bądź pękniętego habitusu) uczynił z nich obcych, zarówno w stosunku do wspólnoty rolniczej, jak

\footnotetext{
4 Zobacz: Husserl (2013), Schutz (1973-1989) i Merleau-Ponty (2001)

${ }^{5}$ Klarowne omówienie ontologicznego i epistemicznego statusu dyspozycji jako składników umysłu i ciała oraz kwestii tego, czy odnoszą się one do przyczynowych czy raczej funkcjonalnych wyjaśnień znaleźć można w Mumford (2003), szerszy obraz zaś w Damschen i in. (2009).
} 
i gospodarki miejskiej, a dalej, przekształcił w żywe nośniki sprzeczności strukturalnych, które pchnęły kraj do rewolucji (Bourdieu 2004 [1962]; Bourdieu i Sayad 2004 [1964]).

Bardziej analityczne rozwinięcie teorii habitusu Bourdieu, oparte na krytyce fenomenologii Sartre'a i strukturalizmu Lévi-Strauss'a znalazło się w wydanym na początku lat siedemdziesiątych S Słkicu teorii praktyki (2007). W pracy tej i kolejnych pismach, zwłaszcza w opublikowanych ćwierć wieku później Medytacjach Pascalianskich (Bourdieu 2006), Bourdieu pokazał, że praktyka nie jest ani mechanicznym efektem nakazów strukturalnych, ani owocem intencjonalnego poszukiwania celów przez jednostki; pozostaje raczej:

produktem dialektycznej relacji między sytuacją a habitusem, rozumianym jako system trwałych i przekazywalnych dyspozycji, który, obejmując wszystkie przeszłe doświadczenia, działa w każdej chwili jak matryca postrzeżeń, ocen i działań i umożliwia wypełniania nieskończenie zróżnicowanych zadań dzięki analogicznym transferom schematów uzyskanych w poprzedniej praktyce (Bourdieu 2007, 197, tłum. zmienione).

Jako indywidualna i grupowa historia osadzona w ciele, struktura społeczna zamieniona w strukturę mentalną i motor sensoryczny, habitus może być pomyślany jako analogiczny do „gramatyki generatywnej” Noama Chomsky'ego (1966). Umożliwia ona osobom posiadającym kompetencje językowe bezrefleksyjne wytwarzanie prawidłowych aktów mowy, zgodnie z powszechnie uznanymi regułami - w sposób twórczy, ale jednocześnie przewidywalny. Zjawisko to oznacza praktyczną kompetencję, uzyskana popržez driałanie i dla działania, która funkcjonuje poniżej poziomu świadomości i jest nieustannie doskonalona w każdym momencie jej zastosowania. Ale w odróżnieniu od gramatyki Chomsky'ego, (i) habitus zawiera nie naturalną, ale społecænna zdolność, która z tego właśnie powodu jest zróżnicowana ze względu na czas i miejsce, a nade wszystko ze względu na dystrybucję władzy; (ii) habitus jest transferowalny do różnych obszarów praktyki, co wyjaśnia zasadniczą spójność, widoczną na przykład w rozmaitych dziedzinach konsumpcji - muzyce, sporcie, jedzeniu i umeblowaniu mieszkań, ale także w wyborach matrymonialnych i politycznych - w jednostkach i pomiędzy jednostkami tej samej klasy; przyczyniając się w ten sposób do ugruntowania ich

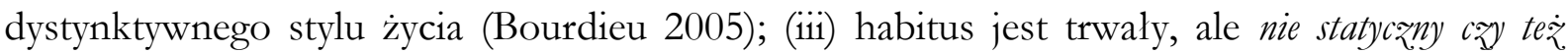
wieczny: dyspozycje są kształtowane społecznie, ale moga ulec erozji, podważeniu lub nawet całkowitemu rozbiciu spowodowanemu przez wystawienie na nowe siły zewnętrzne; przykładem czego może być sytuacja migracji bądź specjalistyczne szkolenie, (iv) wszelako habitus wyposażony jest we wbudowana bezwładność, o tyle, o ile zdolny jest on do wytwarzania praktyk uwzorowanych zgodnie ze strukturami społecznymi, które je generują, i ponieważ każdy z jego poziomów działa jak pryzmat, poprzez który filtrowane są późniejsze doświadczenia, a kolejne warstwy dyspozycji nakładają się na siebie (dlatego też nieproporcjonalną wagę mają schematy nabyte w dzieciństwie, w tym binarna opozycja między męskim a żeńskim); (v) habitus zatem wprowadza opóźnienie, a czasem rozæiew między 
przeszłymi uwarunkowaniami, które go wytworzyły a obecnymi wpływami, które się doń odnoszą (inerpellate):

[Jako] historia, która stała się natura [habitus] nadaje praktykom ich względną niezależność w stosunku do zewnętrznych uwarunkowań bezpośredniej teraźniejszości. Owa autonomia rodzi się z przeszłości, działającej niegdyś i teraz, która funkcjonując jako zakumulowany kapitał, wytwarza historię na bazie historii, i ten sposób zapewnia ciagłość w zmianie, sprawiającej, że jednostkowy podmiot jest światem w świecie (Bourdieu 2008, s. 76, tłum. zmienione)

A zatem teoria habitusu, w przeciwieństwie do strukturalizmu, uznaje, że podmioty działające, angażując swe wcielone instrumenty poznawcze, aktywnie tworzą świat społeczny; jednocześnie teoria ta utrzymuje, w przeciwieństwie do konstruktywizmu, że owe instrumenty same w sobie są wytworzone przez świat społeczny - poprzez somatyzację relacji społecznych. Społecznie usytuowany podmiot „determinuje [się] o tyle, o ile konstruuje sytuację, która go determinuje”, przy czym „nie wybrał on zasady swojego wyboru”; w konsekwencji więc „habitus pomaga zdeterminować to, co go przekształca” (Bourdieu 2006, 212)

Habitus realizuje jednocześnie zasadę socjacji i indywiduacji: socjacji, ponieważ nasze kategorie oceny, odczuwania i działania wywodzą się ze społeczeństwa, są podzielane przez wszystkich tych, których poddano podobnym uwarunkowaniom społecznym (dlatego można mówić o habitusie męskim, habitusie mieszczańskim, habitusie narodowym etc., które odnoszą się do głównych „zasad widzenia i podziału”, ale także habitusie artystycznym, habitusie prawniczym, habitusie więziennym, odpowiadającym specyficznym instytucjom); indywiduacji - o tyle, o ile każda osoba, z racji posiadania wyjątkowej trajektorii i takiegoż usytuowania w świecie, internalizuje unikalną kombinację schematów (nawet bliźnięta jednojajowe oddzielone są kolejnością urodzenia i traktowane w odmienny sposób przez rodziców i inne osoby). Ponieważ habitus jest zarówno ustrukturyz-owany (structu-red) (przez przeszłe środowisko społeczne), jak i struktu-ryzujacy (structu-ring) (obecna percepcję, emocje i działania), działa on jako „niepochodząca z wyboru zasada wszystkich wyborów” (Bourdieu 2008, 82), kierując praktykami, które przyjmują systematyczny charakter strategii, mimo że nie są one rezultatem strategicznej intencji i są obiektywnie ,zorkiestrowane bez organizującego działania jakiekolwiek dyrygenta" (Bourdieu 2008, 73, tłum. zmienione). Jako konstrukcja wielowymiarowa (multi-scalar), habitus pozwala nam łączyć badania ogólne, mające na celu uchwycenie wspólnych elementów występujących pomiędzy koncentrycznymi kręgami uwarunkowań społecznych, ze skupieniem się na tym, co specyficzne, torując w ten sposób droge dla socjologii klinicznej, zdolnej do wejścia w głębiny określonej bio-historii bez redukowania jej do cech ściśle jednostkowych.

Zgodnie z tą dyspozycjonalną filozofią działania, dla której „uspołecznione ciało nie stoi w opozycji do społeczeństwa”, ale konstytuuje ,jedną z form jego egzystencij” (Bourdieu 
1980, 29), aktor społeczny nie jest ani wyizolowanym, egoistycznym indywiduum neoklasycznej teorii ekonomicznej, maszyną kalkulująca, dążącą do maksymalizacji korzyści zawartych $\mathrm{w}$ jasno sprecyzowanych celach, ani też bezcielesnym manipulatorem symbolami, który, jak chce neokantowska tradycja antropologii symbolicznej czy neopragmatyczny nurt interakcjonizmu Meada, w jakiś sposób wolny ma być od oddziaływań sił materialnych (poza jadowitym sporem w kwestii ostatecznej supremacji, czy to interesów, czy to kultury, obie koncepcje działania, racjonalnego aktora i zwierzęcia symbolicznego, są w równym stopniu spontanicystyczne, momentalistyczne i intelektualistyczne). Jednostka, według teorii dyspozycjonalnej, pozostaje odczuwającą istotą z krwi i kości, uwarunkowaną koniecznością historyczna, uwikłaną w świat poprzez nieprzejrzystą relację „ontologicznego współudziału” lub wrogości, co też czasem ma miejsce - powiązaną z innymi od wewnątrz „milczącym porozumieniem”, rozwiniętym na bazie wspólnie podzielanych kategorii percepcji, działania i uznania (Bourdieu 2006, 206)

Prześledzenie filozoficznych źródeł i wczesnych zastosowań habitusu przez Bourdieu - które wyjaśniały historyczne zerwania, spowodowane czy to wojną wyzwoleńczą w Algierii, czy to powojenna modernizacją francuskiej wsi - pozwala na skorygowanie czterech uporczywie powracających nieporozumień dotyczących tego pojęcia.

Po pierwsze, habitus nie jest nigdy replika pojedynczej struktury społecznej, stanowi raczej wielopoziomowy $i$ dynamiczny zestaw schematów, które rejestruja, przechowuja i podtrzymuja wpływ zróżnicowanych środowisk społecznych, poprzez które jednostka przechodzi przez całe swoje życie. Oznacza to, że:
prawdziwa socjogeneza dyspozycji konstytuujących habitus winna dążý do zrozumienia, w jaki sposób porządek społeczny ujmuje, kanalizuje, wzmacnia bądź blokuje procesy psychiczne, w zależności od homologii i redundancji, bądź przeciwnie - od sprzeczności i napięcia między tymi dwiema logikami. Jest więc rzeczą oczywistą, że struktury mentalne nie są prostym odbiciem struktur społecznych (Bourdieu 1993, 717).

Elastyczność habitusu spowodowana jego „permanentną rewizją” realizowaną w praktyce została jeszcze bardziej naświetlona przez Bourdieu poprzez wprowadzenie kardynalnego rozróżnienia, uwidaczniającego się w jego wczesnych badaniach nad edukacją płcią i klasa (Bourdieu, Passseron 1990), a przedstawionego w udramatyzowanej formie w moich studiach nad kategoriami, umiejętnościami i pragnieniami bokserów (Wacquant 2004). Jest to różnica między habitusem pierwotnym, nabywanym we wczesnym dzieciństwie poprzez osmozę w mikrokosmosie rodzinnym i jemu podobnych środowiskach społecznych, oraz habitusem wtórnym, wszczepianym później na bazie tego pierwszego przez wyspecjalizowaną pracę 
pedagogiczną szkoły i innych instytucji dydaktycznych (klub bokserski, malarskie atelier, sekta religijna, partia polityczna etc.). Efektem jest kompromisowa formacja, która w ciagu całego cyklu życia jednostki wyraża jej ogólne i specyficzne dyspozycje w formie zestawu schematów operacyjnych ${ }^{6}$.

Po drugie, wynika z tego, że habitus niekoniecznie jest koherentny i spójny. Odznacza się raczej zróżnicowanymi poziomami integracji i napięcia, w zależności od charakteru i zgodności sytuacji społecznych, które go w miarę upływu czasu kształtuja. Sekwencja zbieżnych instytucji i stabilnych mikrokosmosów społecznych będzie przejawiać tendencję do kształtowania spójnego habitusu, którego kolejne warstwy będą się wzajemnie wzmacniać i funkcjonować harmonijnie. Natomiast organizacje zakorzenione w rozbieżnych wartościach bądź uniwersa entropijne będą kształtować niestabilne systemy przeciwstawnych dyspozycji, w konsekwencji czego wygeneruja nieregularne i niespójne linie działania. Taki rozbity czy też rozczepiony habitus był powszechny wśród algierskiego subproleteriatu badanego przez Bourdieu we wczesnych latach 60 , podobnie jak wśród prekariatu chicagowskiego hipergetta ${ }^{7}$.

Po trzecie, habitus jest tak samo odpowiedni dla analizowania krysysu $i$ zmiany na różnych poziomach - od jednostki do największego makrokosmosu - jak do badań spójności i trwania. Wynika to z tego, iż habitus niekoniecznie pozostaje w zgodności ze światem społecznym, w którym się rozwija. Bourdieu ostrzegał wielokrotnie, aby „unik[ać] nieświadomej uniwersalizacji modelu quasi-kolistej relacji niemal doskonałej reprodukcji, która jest w pełni możliwa tylko wtedy, gdy warunki wytwarzania habitusu i warunki jego funkcjonowania są identyczne bądź homotetyczne" (Bourdieu 2008, 83). To, że habitus może „nie wypalić” i miewać „krytyczne momenty niezgodności i rozdźwięku”, gdy jest niezdolny do wygenerowania praktyk zgodnych z danym środowiskiem, stanowi główne źródło osobistego oporu, innowacji społecznej i zmiany strukturalnej (Bourdieu 2006, 230) ${ }^{8}$.

$\mathrm{Na}$ koniec trzeba podkreślić, że habitus nie jest samowystarczalnym mechanizmem generującym działanie: tak jak sprężyna wymaga on zewnętrznego spustu, nie może być więc analizowany w odseparowaniu od konkretnych światów społecznych (lub ostatecznie pól),

\footnotetext{
${ }^{6}$ Przykładem studium, które ujmuje zarówno ogólne (odnosząc się do maskulinistycznej kultury całego kraju), jak i specyficzne (organizacyjne) komponenty konkretnego habitusu jest pozycja Desmonda (2007); szersze omówienie analitycznych implikacji i odmian ,generacji” habitusu zob. Wacquant (2014).

${ }^{7}$ Bourdieu (1977) i Wacquant (1998). Zob. także wnikliwą analizę Bourdieu „rozszczepionego habitusu” Édouarda Maneta, będącego „syntezą opozycji”: z jednej strony konformistycznego burżua, z drugiej zbuntowanego artysty, czego efektem było „zdumiewające napięcie” prowadzące do innowacji artystycznej (2014, 454-463 i 648-651).

${ }^{8}$ Oznacza to, że teoria habitusu nie musi być w żaden sposób „uzupełniana”, by móc uchwycić „kreatywne działanie" przeciwstawione reprodukcji (Joas 1997), wielość temporalności i struktur (Sewell 2005, rozdz. 4) lub też by na nowo odkryć „działający podmiot” (acting subject), świadomy ukrytych możliwości historycznych (Ortner 2006).
} 
w których funkcjonuje. Co więcej, ten sam habitus zaowocuje różnymi ścieżkami działania, jeżeli napotka odmienne możliwości strategiczne. Wnikliwa analiza dyspozycji musi więc przebiegać w ścisłym związku z odwzorowaniem całego systemu pozycji, które naprzemiennie pobudzają, tłumią bądź przekierowuja skłonności podmiotu działającego. Taka dwustronna, dynamiczna wajemna praekładnia ucielesnionych $i$ zobiektywizowanych struktur społecznych jest kolejnym potencjalnym źródłem przekształceń zarówno osoby, jak i kosmosu społecznego:

Kiedy nie ma obiektywnych warunków urzeczywistnienia habitusu, a dana sytuacja nieustannie go blokuje, habitus potrafi stać się miejscem koncentracji wybuchowych sił społecznych (takich jak resentyment), które mogą oczekiwać (lub nawet aktywnie szukać) możliwości swojego spełnienia i wyrazić się, jeżeli tylko zaistnieją sprzyjające ku temu obiektywne warunki (np. pozycja małostkowego szefa)... Sprzeciw wobec mechanicyzmu chwili prowadzi do podkreślania „asymilatywnych” zdolności habitusu, lecz habitus oznacza również adaptację: dopasowuje się nieustannie do świata, co tylko wyjątkowo przybiera formę radykalnej konwersji (Bourdieu 1980, 135-136).

Pełne wyjaśnienie praktyki wymaga zatem potrójnego, skoordynowanego objaśnienia: genezy społecznej i struktury habitusu jako uhistorycznionej subiektywności; formowania i dynamiki przestrzeni społecznej jako historycznej dystrybucji możliwości (które, w pewnych ograniczonych przypadkach, przybieraja formę pola); oraz konkretnych przypadków mikrodialektycznej konfrontacji pozycji i dyspozycji.

Mimo że filozofowie tacy jak John Searle (1999), Jacques Bouveresse (1995), Charles Taylor (1999) i Iris Marion Young (2005) omawiali opracowana przez Bourdieu koncepcję habitusu w odniesieniu do filozofii umysłu, języka czy jaźni, a neurobiolog Jean-Pierre Changeux (2004) powiązał habitus z obecnymi badaniami na mózgiem, umieszczając go w naszej strukturze synaptycznej, podkreślić należy, że dla samego Bourdieu habitus nie jest abstrakcyjną koncepcją będącą wynikiem teoretycznych dywagacji i przeznaczoną dla tego typu rozważań; jest on przede wszystkim stenograficznym sposobem wyznaczania postawy badawczej. Habitus stawia w sercu analizy społecznej genetyczny sposób myślenia, i w ten sposób kieruje nas ku odkopywaniu ukrytych kognitywnych, konatywnych i emotywnych konstruktów, za pomoca których jednostki poruszają się w przestrzeni społecznej i pobudzają swój świat przeżywany. Jest tak, ponieważ połączone i społecznie ukonstytuowane schematy, które czynią jednostkę wprawnym i posiadającym różne pragnienia podmiotem działającym, są w pełni dostępne dla metodycznej obserwacji i analitycznego rozbioru. Ostatecznie wartość teorii habitusu winna być sprawdzana w empirycznej praktyce.

\section{Przetozyt Tomasz. W arczok}




\section{Wykaz literatury}

Arystoteles. 2016. Etyka nikomachejska. Tłum. Daniela Gromska. Warszawa: PWN.

Bourdieu, Pierre. 1977. Algeria 1960. Cambridge: Cambridge University Press.

Bourdieu, Pierre. 1980. Questions de sociologie. Paris: Minuit.

Bourdieu, Pierre. 1993. 'Les contradictions de l'héritage'. W La Misère du monde, Paris: Seuil.

Bourdieu, Pierre. 2004. 'The peasant and his body'. Tłum. Ethnography, 5 (4): 579-598

Bourdieu, Pierre. 2005. Dystynkcja. Spoteczna krytyka władzy sadzenia. Tłum. Piotr Biłos.

Warszawa: Scholar.

Bourdieu, Pierre. 2006. Medytacje pascalianskie. Tłum. Krzysztof Wakar, Ewa Klekot.

Warszawa: Oficyna Naukowa.

Bourdieu. Pierre. 2007. S Zkic teorii praktyki, poprzedzony trzema studiami na temat etnologii Kabylów.

Tłum. Wiesław Kroker. Kęty: Antyk Wydawnictwo-M.Derwiecki.

Bourdieu, Pierre. 2008. Zmyst praktyczny. Tłum. Maciej Falski. Kraków: Wydawnictwo UJ.

Bourdieu, Pierre. 2014. Manet. Une révolution symbolique, Paris: Seuil.

Bourdieu, Pierre, Passeron, Jean-Claude .1990. Reprodukcja. Elementy teorii systemu nauczania. Tłum. Elżbieta Neyman Warszawa: PWN.

Bourdieu, Pierre, Sayad, A. 2004. 'Colonial rule and cultural sabir', Ethnography, 5 (4): 444-486 także Le Déracinement. La crise de l'agriculture traditionnelle en Algérie, Paris: Minuit, 1964.

Bourke, V. J. 1942. 'The role of habitus in the Thomistic metaphysics of potency and act', W: R. E. Brennan (red.), Essays in Thomism, 103-109, New York: Sheed and Ward.

Bouveresse, J. 1995. 'Règles, dispositions et habitus', Critique, 51: 573-594.

Changeux, J.-P. 2004. L'Homme de vérité, Paris: Odile Jacob.

Chomsky, Noam. 1966. Topics in the Theory of Generative Grammar, Berlin: Walter de Gruyter.

Damschen, G., Schnepf, R. and Stüber, K. (red.), 2009. Debating Dispositions: Issues in Metaphysics, Epistemology and Philosophy of Mind, New York: Walter de Gruyter.

Desmond, M. 2007. On the Fireline: Living and Dying with Wildland Firefighters.Chicago: University of Chicago Press.

Durkheim, Émile. 1990 [1924]. L'Évolution pédagogique en France. Paris: PUF; tr. The Evolution of Educational Thought: Lectures on the Formation and Development of Secondary Education in France, London: Routledge, 1977.

Elias, Norbert. 2014. O procesie cywilizacji. Tłum. Tadeusz Zabłudowski, Kamil Markiewicz Warszawa: Wydawnictwo W.A.B.

Husserl, Edmund. 2013. Dośviadczenia i sqd. Tłum. Bogdan Baran. Warszawa: Aletheia. Joas, Hans. 1997. The Creativity of Action. Chicago: University of Chicago Press.

Joas, Hans, Knöbl, W. 2009. Social Theory: Twenty Introductory Lectures, Cambridge: Cambridge University Press.

Mauss, Marcel. 2001. Sposoby postugiwania sie ciałem W: M. Mauss, Socjologia i antropologia. Tłum. Marcin Król. Warszawa: Wydawnictwo KR.

Merleau-Ponty, Maurice. 2001. Fenomenologia percepcji. Tłum. Małgorzata Kowalska, Jacek Migasiński. Warszawa: Alatheia.

Ortner, Sherry B. 2006. Anthropology and Social Theory: Culture, Power, and the Acting Subject, Durham, NC: Duke University Press.

Schutz, A. 1973-89. Structures of the Lifeworld, Evanston, IL: Northwestern University Press. 
Searle, J. R. 1998. Umyst na nowo odkryty, Tłum. Baszniak Tadeusz. Warszawa: PIW.

Sewell, William H. Jr. 2005. Logics of History: Social Theory and Social Transformation, Chicago: University of Chicago Press.

Taylor, C. 1999. 'To follow a rule', W: Richard Schusterman (red.), Bourdieu: A Critical Reader, 29-44, Cambridge: Wiley-Blackwell.

Veblen, T. 2008 [1899], Teoria klasy próżniaczej. Tłum. Zagórska Janina, Zagórski Krzysztof. Warszawa: Muza SA.

Wacquant, Loïc. 1998 [1992]. 'Inside the zone: the social art of the hustler in the black American ghetto', Theory, Culture \& Society, 15 (2): 1-36.

Wacquant, Loïc., 2012. „Na tropach badań terenowych Pierre’a Bourdieu”, Studia Litteraria et Historica, 1:1-18.

Wacquant, Loïc. 2004b. Body and Soul: Notebooks of an Apprentice Boxer, New York: Oxford University Press, new expanded ed. 2016.

Wacquant, Loïc. 2014. 'Homines in extremis: what fighting scholars teach us about habitus', Body \& Society, 20 (2) (June, Symposium with responses by Nick Crossley, Greg Downey, Hélène Mialet, and Élise Paradis): 3-17.

Weber, Max. 2002. Gospodarka i społeczeństwo. Zarys socjologii rozumiejacej. Tłum. Danuta Lachowska. Lachowska Dorota. Warszawa: PWN.

Young, Iris Marion. 2005. On Female Body Experience: 'Throwing Like a Girl' and Other Essays. New York: Oxford University Press. 
Loïc Wacquant - profesor socjologii na Uniwersytecie Kalifornijskim w Berkeley oraz pracownik naukowy w Centre de sociologie européenne w Paryżu. Jego zainteresowania obejmuja problematykę marginalizacji miejskiej, polityki karania, cielesności i teorii społecznej. Jest laureatem prestiżowej nagrody MacArthur Prize Fellow, jego książki przetłumaczono na ponad dwadzieścia języków, między innymi Body and Soul: Notebooks of An Apprentice Boxer (2004, nowe rozszerzone wydanie, 2016), The Two Faces of the Ghetto (2016), and Tracking the Penal State (2016). Więcej informacji znaleźć można na stronie domowej: loicwacquant.net.

\section{DANE ADRESOWE:}

Loïc Wacquant

Department of Sociology

University of California, Berkeley

Berkeley, CA 94720, USA

EMAIL: loic@berkeley.edu

CYTOWANIE: Wacquant, Loïc. 2016. Zwięzła genealogia i anatomia habitusu. Praktyka Teoretyczna 3 (21): 163-173.

DOI: $10.14746 /$ prt.2016.3.7

\section{AUTHOR: Loïc Wacquant}

TITLE: A Concise Genealogy and Anatomy of Habitus

ABSTRACT: Retracing the philosophical origins and initial usage of habitus by Bourdieu to account for the historical disjuncture wrought by theAlgerianwar of national liberation and the postwar modernization of the French countryside allows us to clear up four recurrent misunderstandings about the concept: (1) habitus is never the replica of a single social structure but a dynamic, multiscalar, and multilayered set of schemata subject to 'permanent revision' in practice; (2) habitus is not necessarily coherent and unified but displays varying degrees of integration and tension; (3) because it is not always congruent with the cosmos in which it evolves, habitus is suited to analysing crisis and change no less than cohesion and perpetuation; but (4) it is not a self-sufficient mechanism for the generation of action: the dissection of dispositions must always proceed in close connection with the mapping of the system of positions that alternately excite, suppress, or redirect the socially constituted capacities and inclinations of the agent. Crucially, in Bourdieu's hands, habitus is not an abstract concept issued from and aimed at theoretical disquisition, but a stenographic manner of designating a research posture that puts the genetic mode of thinking at the heart of social analysis.

KEYWORDS: habitus, Bourdieu, embodiment, schemata, disjuncture, historicization, philosophy of consciousness 